\title{
PRÁTICAS AFRORRELIGIOSAS, LITERATURA E ENSINO DE HISTÓRIA: \\ por uma educação decolonial
}

$V$ anda Fortuna Serafim

Lais Arevedo Fialho

Resumo

A finalidade desse artigo é pensar possibilidades para o ensino da história e cultura afro-brasileira por meio da literatura, atentando às práticas afrorreligiosas, mas problematizando os discursos colonizadores presentes na maioria das narrativas existentes. A obra literária escolhida para tanto consiste em Deuses de dois mundos - a trilogia épica dos orixás, de autoria de PJ Pereira, que teve amplo sucesso literário, especialmente entre o público juvenil, e chama a atenção pelo modo como o autor contava uma história contemporânea utilizando os mitos dos orixás, tornando-se uma boa ferramenta para o ensino de história e cultura afrobrasileira. Rica em detalhes sobre a cultura iorubana, ainda assim, exige preparo do (a) professor (a) para reconhecer o processo de "embranquecimento cultural" operado na obra.

Palavras-chave: ensino de história; educação decolonial; história e cultura afro-brasileira.

AFRICAN-RELIGIOUS PRACTICES, LITERATURE AND HISTORY TEACHING: for decolonial education

\begin{abstract}
The purpose of this article is to think about possibilities for teaching African-Brazilian history and culture through literature, paying attention to African-religious practices, but problematizing the colonizing discourses present in most of the existing narratives. The literary work chosen for this purpose consists of Deuses de dois mundos - a trilogia épica dos orixás, authored by PJ Pereira, which had wide literary success, especially among the youth audience, it is remarkable how the author tells a contemporary story using the myths of the Orishas, being a way to teach African-Brazilian history and culture. The work is rich in details about Yoruban culture, yet it requires preparation by the teacher to recognize the process of "cultural whitening" operated in the book.
\end{abstract}

Keywords: history teaching; decolonial education; african-Brazilian history and culture.

PRÁCTICAS AFRORELIGIOSAS, LITERATURA Y ENSEÑANZA DE HISTORIA: para la educatión descolonial

Resumen

El propósito de este artículo es pensar en las posibilidades de enseñar la historia y la cultura afrobrasileña a través de la literatura, prestando atención a las prácticas afroreligiosas, pero problematizando los discursos colonizadores presentes en la mayoría de las narraciones existentes. La obra literaria elegida para este propósito consiste en Deuses de dois mundos - a trilogia épica dos orixás, creada por PJ Pereira, que tuvo un gran éxito literario, especialmente entre el público juvenil, y llama la atención por la forma en que el autor contó una historia contemporânea, utilizando los mitos del orishas, convirtiéndose en una buena herramienta para enseñar la historia y cultura afrobrasileña. El trabajo es rico en detalles sobre la cultura 
yorubana, pero requiere la preparación del maestro para reconocer el proceso de "blanqueamiento cultural" operado en el trabajo.

Palabras clave: enseñanza de la historia; educación descolonial; historia y cultura afrobrasileña.

\title{
INTRODUÇÃO
}

Observamos que, no Brasil, poucas medidas indicam que a sociedade e o Estado assumiram um dever de memória para com as populações afrodescendentes, no que se refere à escravidão. Identificamos algumas medidas como tentativas de combater esse esquecimento, como a Lei no 10.639/03, alterando a Lei de Diretrizes e Bases da Educação, que incluiu no currículo oficial da Rede de Ensino a obrigatoriedade da presença da temática "História e Cultura Afro-Brasileira e Africana" e estabeleceu a data 20 de novembro como o Dia da Consciência Negra. A lei justificase assim:

\begin{abstract}
A demanda por reparações visa a que o Estado e a sociedade tomem medidas para ressarcir os descendentes de africanos negros, dos danos psicológicos, materiais, sociais, políticos e educacionais sofridos sob o regime escravista, bem como em virtude das políticas explícitas ou tácitas de branqueamento da população, de manutenção de privilégios exclusivos para grupos com poder de governar e de influir na formulação de políticas, no pós-abolição. Visa também a que tais medidas se concretizem em iniciativas de combate ao racismo e a toda sorte de discriminações (BRASIL, 2003, p.10).
\end{abstract}

Se observamos de quando é datada essa lei, notaremos quão tardia foi tomada uma medida em que o Estado brasileiro se propõe a lidar com a questão de combate ao racismo e reconhecimento da história de resistência dos afrodescendentes. Além disso, medidas como essa são fruto de lutas do movimento negro, que pautam questões sociais e antirracistas e demonstram a necessidade de discutir o racismo e trazer para o espaço público as memórias diaspóricas que a população afro-brasileira carrega consigo (GOMES, 2012).

A Lei n 10.639/2003 resulta de um processo de reivindicações de coletivos organizados por pessoas negras, que pautam representatividade afro-brasileira nos espaços socioeducativos. Essa representatividade busca positivar, legitimar e democratizar o acesso às histórias de resistências de quilombolas, povos de terreiros e outros grupos negros que, historicamente, foram deturpadas pela história oficial e pelos discursos proferidos por homens brancos, que não puderam olhar para essa história com um mínimo de alteridade. Sendo assim, essa medida não pode ser considerada uma iniciativa do Estado ou da sociedade, que não teriam chegado a essas ações, não fosse a histórica atuação do movimento negro (GONÇALVES, 2010).

Torna-se imperativo que as africanidades, repertórios culturais de herança africana que compõem a cultura brasileira e tornam negros e negras sujeitos da história, integrem o currículo e a educação escolar (LIMA, 2008). Os modos de civilidade dessa população devem estar presentes, operando na construção de imaginários que contrapõem a "colonialidade do saber". Assim, a decolonidade mostra-se como uma alternativa para o ensino de história, que até os dias atuais ancorou-se, majoritariamente, no modo de produzir conhecimento posto pela modernidade europeia. Ou seja, reproduziu um conhecimento que se baseia no dualismo entre razão e emoção, modernidade e atraso, alma e corpo e na noção temporal de evolução. Produz uma lógica binária que desperdiça experiências cognitivas e hierarquiza culturas com base no espelho europeu (QUIJANO, 2005). 
O ensino de história comprometido com uma educação decolonial possibilita a compreensão da historicidade das lógicas coloniais postas, apontando para a intolerância, o racismo e o genocídio. Além disso, potencializa uma formação que promova o exercício ético da alteridade, e da capacidade de produzir novos modos de se relacionar com os outros. Dentro dessa proposta, abordar a história dos orixás, por meio da literatura, pode se constituir no que Simas e Rufino (2018) nominam como "terreirização dos espaços de saber".

Para utilizar a literatura no ensino de história apontamos alguns cuidados metodológicos. As obras não devem ser tomadas como fantasias, mas como representações da realidade, localizadas em um tempo, espaço, e lugar social. Assim, apontamos que a literatura possibilita o acesso a imaginários, evidencia traços e pistas que outros documentos não apresentariam (PESAVENTO, 2006). O trabalho pedagógico que relaciona história e literatura deve elencar temáticas que dialoguem com problemáticas pertinente ao tempo. Precisam ser acompanhadas de questionamentos sobre a produção e circulação da obra, tais como os autores, locais de produção, datas, importância, etc.

Exposto isso, a finalidade desse artigo é pensar possibilidades para o ensino da história e cultura afro-brasileira por meio da literatura, atentando às práticas afrorreligiosas, mas problematizando os discursos colonizadores presentes na maioria das narrativas existentes.

A obra literária escolhida para tanto consiste em Deuses de dois mundos - a trilogia épica dos orixás, de autoria PJ Pereira, que nasceu em 1973, na cidade do Rio de Janeiro, formou-se em administração com especialização em marketing, trabalhou como publicitário na cidade de São Paulo anos antes de iniciar uma carreira em São Francisco, Estados Unidos, onde montou uma agência de publicidade - Pereira \& O’Dell - que já recebeu diversos prêmios internacionais (PACHECO, 2013). PJ Pereira (2015) declara que desconhecia as religiões afro-brasileiras e suas divindades, inclusive admite que nutria muito preconceito contra o candomblé e que, durante toda a sua vida, havia sido exposto a ideias que diziam que o candomblé era uma coisa perigosa, ruim, que ele deveria manter distância (LEÃO, 2015). Quando conheceu Zeno Millet, neto de Mãe Menininha do Gantois ${ }^{1}$ (1894-1986), quem lhe apresentou alguns aspectos do candomblé, resolveu se aproximar da religião. Ele diz que começou a pesquisar sobre o candomblé a fim de desconstruir as ideias preconcebidas acerca das religiões de matriz africana. Menciona que, ao passo em que foi se aprofundando em suas pesquisas, foi se interessando cada vez mais pela mitologia ioruba e percebendo que a riqueza do candomblé e as mitologias africanas são importantes para formação cultural do Brasil.

PJ Pereira decidiu então focar exclusivamente neste trabalho, que levou mais de dez anos de pesquisa, entre entrevistas - com aproximadamente 50 adeptos de candomblé, apresentados por Zeno Milett - visitas a alguns terreiros, em especial o Terreiro do Gantois ${ }^{2}$ e pesquisas bibliográficas (CUNHA, 2014). Assim, em 2003, escreveu a ficção em um único volume de 900 páginas. Nenhuma editora se interessou pela obra no período. Somente dez anos depois, quando teve seu

\footnotetext{
${ }^{1}$ Maria Escolástica da Conceição Nazaré, conhecida como Mãe Menininha do Gantois, foi uma das mais admiradas yalorixás (mães de santo) da Bahia e do Brasil.

2 O Ilé Iyá Omi Asé Iyamasé, conhecido como terreiro do Gantois, talvez seja o único no Brasil que preserva em sua direção uma descendente direta das africanas fundadoras do primeiro candomblé de origem iorubana, seguindo a tradição matriarcal. É um templo que segue as regras tradicionais com base na estrutura familiar de manutenção dos laços parentais, em que as dirigentes são sempre do sexo feminino, obedecendo aos critérios de hereditariedade e consanguinidade, com uma linhagem de poderosas sacerdotisas. O terreiro foi fundado em 1849 pela africana liberta Maria Júlia da Conceição Nazareth (1800-1910), no bairro da Federação, em Salvador, Bahia. O terreiro do Gantois foi tombado como patrimônio histórico pelo Iphan, em 2002.
} 
nome reconhecido como publicitário de sucesso, PJ Pereira tentou novamente publicar a história (KUSUMOTO, 2015). A obra foi organizada em três volumes: O livro do silêncio, publicado em 2013; O livro da traição, em 2014; e O livro da morte, em 2015.

A trilogia épica dos orixás teve amplo sucesso literário, especialmente entre o público juvenil, e chama a atenção pelo modo como o autor conta uma história contemporânea utilizando os mitos dos orixás. Não é comum encontrarmos narrativas fantásticas com os mitos dos orixás, nem histórias em que os orixás viajem de tempos em tempos mudando o presente, passado e futuro dos humanos. Tampouco que o enredo apresente uma divindade da comunicação que se comunica com os humanos por e-mail. Todas essas características certamente atraem a atenção dos adolescentes e transformam a obra em uma boa ferramenta para o ensino de história e cultura afrobrasileira. A obra é rica em detalhes sobre a cultura iorubana, em especial as suas divindades, mitos e ritos. Ainda assim, exige preparo do (a) professor (a) para reconhecer o processo de "embranquecimento cultural" operado na obra, como veremos a seguir.

\section{LITERATURA E PUBLICIDADE: DEUSES AFRICANOS E AFRO-BRASILEIROS COMO OBJETOS DE CONSUMO E OS CUIDADOS METODOLÓGICOS NECESSÁRIOS AO ENSINO DE HISTÓRIA}

Partimos da premissa de que não há discursos independentes de uma enunciação simbólica e materialidade que não promovam sua circulação e apropriação. Nas palavras de Roger Chartier (1999, p. 105), “[...] as significações, histórica e socialmente diferenciadas de um texto, qualquer que ele seja, não podem separar-se das modalidades materiais que o dão a ler aos seus leitores"; e mais: “[...] um mesmo texto, fixo em sua letra, não é o 'mesmo' se mudam os dispositivos de sua inscrição ou de sua comunicação (CHARTIER, 2002, p. 256).

Desse modo, se torna imperativo historicizar a nossa fonte e, portanto, destacar os aspectos que envolvem sua materialidade e suporte. Para isso destacamos as condições técnicas de sua produção, que nos permitem localizá-la, uma vez que ela não se enuncia como objeto único e isolado. Propomos analisar Deuses de dois mundos em sua condição material, seu formato textual, tipo de papel e acabamento, qualidade de impressão, layout, tipografia, presença de imagens, estruturação interna de conteúdo, publicidade, relação com o mercado, interesses de publicação, recepção e vendagem.

Ressaltamos que os recursos técnicos e gráficos utilizados na publicação da obra Deuses de dois mundos estão inseridos em uma temporalidade marcada por mudanças no setor editorial, que se relacionam diretamente com o avanço das mídias digitais e com a diversidade de edições possíveis na atualidade. Nesse contexto, a obra busca responder às expectativas das demandas mercadológicas do período.

Sublinhamos também que PJ Pereira (2015) trabalha no campo criativo da propaganda e marketing há décadas e, na atualidade, é internacionalmente reconhecido, sobretudo pelos Daytime Emmy e três Grand Prix que ganhou por campanhas publicitárias no Festival de Cannes. O fato nos interessa porque, conforme o autor, influenciou diretamente na viabilização da publicação da trilogia. Em entrevista para a Revista Época Negócios, diz:

Eu não comecei na propaganda como criativo, mas sabia que queria trabalhar nessa área. Passei um ano frequentando a criação da DM9 depois do dia normal de trabalho, ajudando quem quisesse, até que me deram meu primeiro job e descobriram que eu era, tecnicamente, da mídia [...] Veja meus livros, por exemplo. Nenhuma editora queria publicar. Porque eu não tinha credenciais 
como escritor e diziam que o tema do meu livro não tinha mercado, porque era "para um público que não lê" (o livro é uma obra de ficção inspirada nos orixás, como um Thor africano). Tudo bem. Continuei insistindo. Por 10 anos! De repente, ganhei um Emmy por uma campanha publicitária (a primeira vez que a campanha ganhou um Emmy competindo com conteúdo de televisão) e todo mundo queria publicar. Agora o livro entrou na lista de best-sellers, foi publicado em outros países e eu estou para lançar meu terceiro (PJ PEREIRA, 2014)3.

Consideramos que o preconceito com as religiões afro-brasileiras tenha sido um dos motivos de Deuses de dois mundos não ter encontrado lugar no mercado literário quando PJ Pereira tentou publicar a obra pela primeira vez, em 2003. Teve que esperar dez anos até encontrar uma editora que a publicasse (BAOBÁ, 2015). Acreditamos que, entre outros fatores, a luta do movimento negro e a inclusão de políticas públicas, como a Lei n. 10.639, que torna obrigatório o ensino de história da África e cultura afro-brasileira nas escolas, tenham contribuído para maior aceitação e veiculação de narrativas que falem das divindades cultuadas no candomblé. Mesmo com esse avanço, identificamos que algumas narrativas são privilegiadas no processo de ampliação desse conhecimento. Observamos, portanto, que alguns sujeitos sociais, como o próprio PJ Pereira, têm maior facilidade em transitar entre distintos espaços sociais, podendo se apropriar de dados saberes e representar determinadas práticas, a partir do que Joel Zito Araújo (2006) denomina como persistência consciente ou inconsciente da estética do branqueamento.

Para os adeptos das tradições iorubas, o mito é a chave para alcançar não apenas o passado, mas também o presente e o futuro. O mito ensina quem são as divindades, quais são seus poderes e regências, de onde elas vieram, quais são as suas preferências e interdições e como o homem religioso deve se relacionar com elas. No imaginário iorubano tradicional de mundo, a mitologia fornece sentidos fundamentais para a vida na terra. É ela quem organiza e estrutura a religião dos orixás. Os orixás são os ancestrais divinizados, e os mitos, as narrativas que se repetem ciclicamente de geração em geração na vida de seus descendentes (PRANDI, 2001).

Os iorubas acreditam que o homem descende dos orixás e cada ser humano tem uma linhagem que se refere a um ancestral específico. Cada um herda do seu orixá os seus atributos, predisposições e intentos, de acordo com o que conta os mitos. Os orixás se regozijam e se entristecem, perdem e vencem, avançam e retrocedem, amam e odeiam (PRANDI, 2001). Essas narrativas míticas estão bastantes presentes na estrutura do candomblé, pois se trata de uma oralidade oriunda da Costa Ocidental da África, disseminada para regiões de outros continentes, inclusive o Brasil, na diáspora provocada pelo tráfico escravista ${ }^{4}$. Os mitos, itans em ioruba, foram disseminados no Brasil a partir da memória coletiva de homens e mulheres na condição de escravos. A mitologia foi um dos elementos transmitidos por esse grupo, detentor de uma gama de conhecimentos litúrgicos e ritualísticos, que daria posteriormente origem ao culto dos orixás no país.

Reginaldo Prandi (2001), sociólogo das religiões, é o responsável por realizar o mais significativo dos trabalhos de coleta dos mitos iorubas difundidos no Brasil e em outros países na América Latina. Ele publicou A mitologia dos orixás, compilando 301 mitos: 106 da África, 126 do

\footnotetext{
3 Disponível em http://colunas.revistaepocanegocios.globo.com/mundocriativo/2015/03/23/pj-a-diferenca-e-oberco-da-criatividade/. Acesso em 6 nov. 2018.

${ }^{4}$ No caso do Brasil, conjectura-se que a mitologia ioruba é a mais disseminada, porque os iorubas foram um dos últimos grupos étnicos a serem trazidos para o país, no ciclo da Costa da Mina, no século XVIII, e no ciclo da baía de Benin, entre 1770 e 1850 (VERGER, 1987). Os iorubas também teriam sido empregados em setores urbanos e domésticos, em sua maioria, na cidade de Salvador. Isso teria lhes dado alguma facilidade, em relação aos bantus, para preservar sua língua e religião. O que, na visão dos intelectuais do período, configurou uma superioridade dos iorubas (CASTRO, 2001)
} 
Brasil e 69 de Cuba. Deuses de dois mundos se apropria de muitos dos mitos presentes nesta obra e há muitas correlações nas formas como agem os orixás, suas características principais e seus traços de personalidades nas duas obras. Dessa maneira, a obra busca retratar de forma verossímil muitos dos fundamentos do candomblé. Mesmo assim, traz versões bastante ocidentalizadas dos mitos iorubas, narrativas embranquecidas e, por vezes, atenuantes. É possível que o autor tenha escolhido produzir sua narrativa desse modo para que fosse bem recebida por um amplo leque de leitores. Por isso, enfatizamos a necessidade de pensar como a trilogia épica dos orixás está sendo narrada e subjetivada de um lugar social privilegiado, o da branquitude (ZITO, 2006).

O primeiro volume da trilogia, O livro do silêncio, foi lançado em 2013; o segundo, O livro da traição, em 2014; e o terceiro, O livro da morte, em 2015. Todos em língua portuguesa, pela Editora Livros de Safra, selo Da Boa Prosa - um dos quatro selos da empresa fundada em 2010 pelo escritor Marcelo Cândido de Melo e pela artista plástica Adriana Conti Melo. A proposta era: o selo Alfaiatar prestar assessoria de serviços editoriais e comerciais a autores; o selo Impressão Régia publicar obras de direito; o selo Virgiliae lançar narrativas literárias de linguagem sofisticada; e o selo Da Boa Prosa, livros de ficção e não ficção com algum apelo mercadológico e temática diversificada. O slogan do selo: "[...] Alguns têm algo a dizer, outros a vontade de saber. A Da Boa Prosa faz livros de ficção e não ficção metidos a best-seller, mas que não ferem a sua inteligência"

Supomos que uma literatura que represente divindades do candomblé não tivesse espaço em um selo dedicado à literatura sofisticada; por isso o encaixe no Da Boa Prosa. E, se nos atentarmos ao contexto histórico de publicação da trilogia, marcado pela globalização e grande mercantilização da cultura negra, como aponta Sansone (2000), não nos parecerá incoerente a opção de explorar o apelo mercadológico.

Conforme José Antônio Rosa (2008), o negócio do livro, que era pequeno e descentralizado, tomou grandes proporções na primeira década do século XXI, principalmente, devido ao processo de centralização, no qual empresas de grande e médio porte passaram a ocupar a maior parte do mercado literário. As principais características dessa centralização seria a migração das livrarias para os shoppings, o advento das megastores, grandes lojas, e a utilização da internet para comercialização de livros. Já na segunda década, com a intensificação da crise financeira, o contexto é marcado pelo fechamento de áreas de negócio, vide o caso da Livros de Safra, que não localizamos mais. A nova conjuntura orientada pelo marketing e por critérios ditados pelo mercado provocaram uma grande preocupação com a promoção de lucro em detrimento da promoção da cultura. Mesmo assim, diz o autor, ainda é possível encontrar espaços para empresas pequenas, que buscam preencher as lacunas deixadas pelas grandes editoras, procurando nichos específicos.

Nessa perspectiva, a Livros de Safra buscou explorar um nicho bastante particular ao produzir uma obra fantástica que se apropria da mitologia dos orixás como norteadora de uma narrativa ficcional. Em nossa análise, não identificamos outro livro do selo, ou da editora, que apresentasse conteúdo relacionado às religiões afro-brasileiras.

PJ Pereira (2015) optou pela edição independente da trilogia, em que ele desempenha o papel central, tem autonomia e é responsável pelo produto final. Destacamos que a trilogia se dispôs de diversos canais de publicidade contemporâneos, incluindo um book trailer, produzido pela Laundry Design, de Los Angeles e dirigido por Anthony Liu. Trata-se de uma de animação com duração de dois minutos e cinquenta segundos, com a participação de Gilberto Gil na narração e trilha sonora de Otto, Andreas Kisser (Sepultura) e Pupillo (Nação Zumbi). O conteúdo foi

${ }^{5}$ Fonte: http://www.livrosdesafra.com.br/da-boa-prosa/. Acesso em 6 nov. 2018. Porém, em junho de 2019, todos os links da editora não abrem mais; talvez tenha encerrado atividades, informação que não conseguimos obter. 
DOI: $10.12957 /$ teias.\%Y.51424

publicado, entre outras plataformas, no Youtube e obteve 539.511 visualizações ${ }^{6}$. Na descrição da publicação, que foi realizada a partir da conta de PJ Pereira, constam links de acesso para comprar a obra online, bem como um resumo dela.

Figura 1 - Imagem do book trailer da trilogia

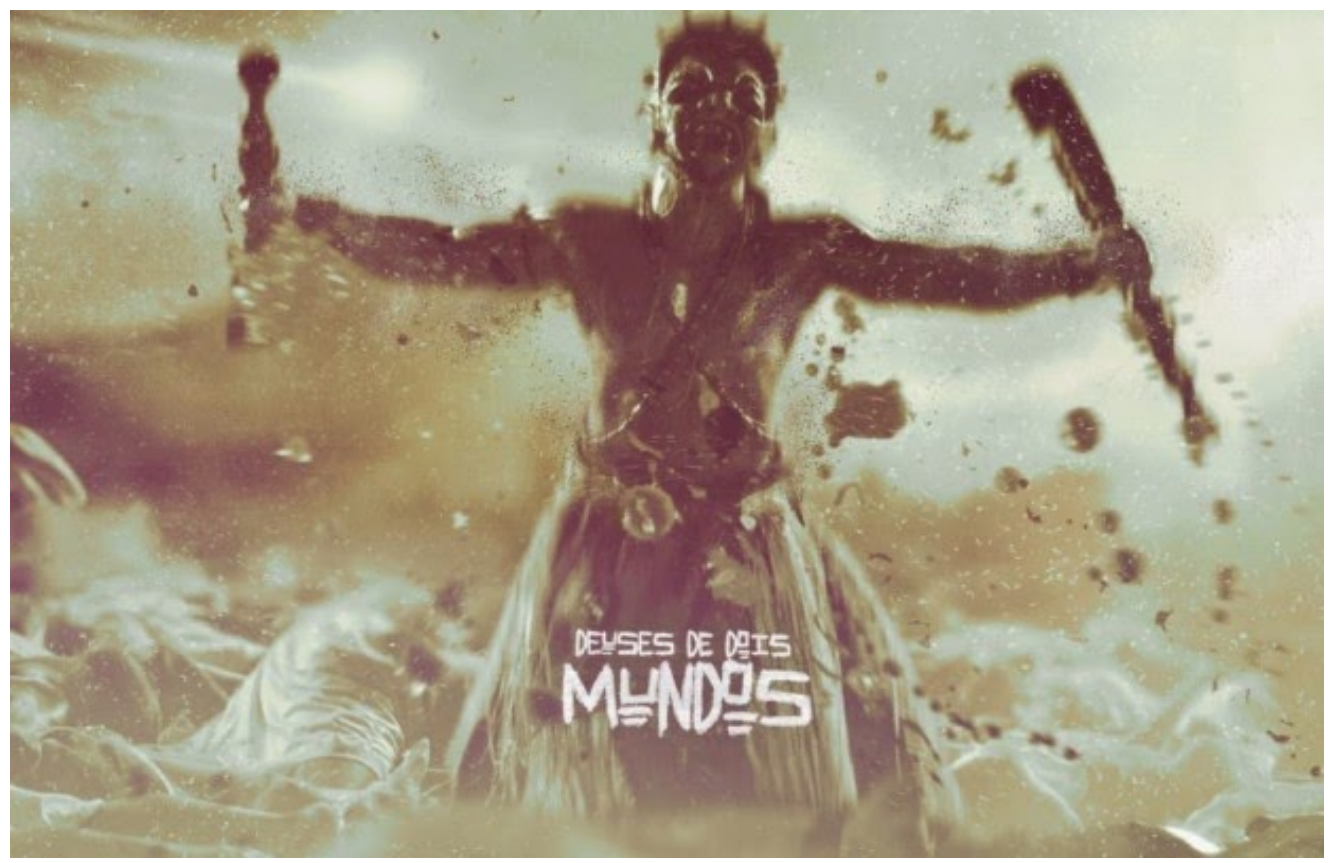

Fonte: https://downloadlivrospdf.wordpress.com/2015/08/29/deuses-de-dois-mundos_-vol-1_livro-dosilencio_pj-pereira/

Figura 2 - Imagem do book trailer da trilogia

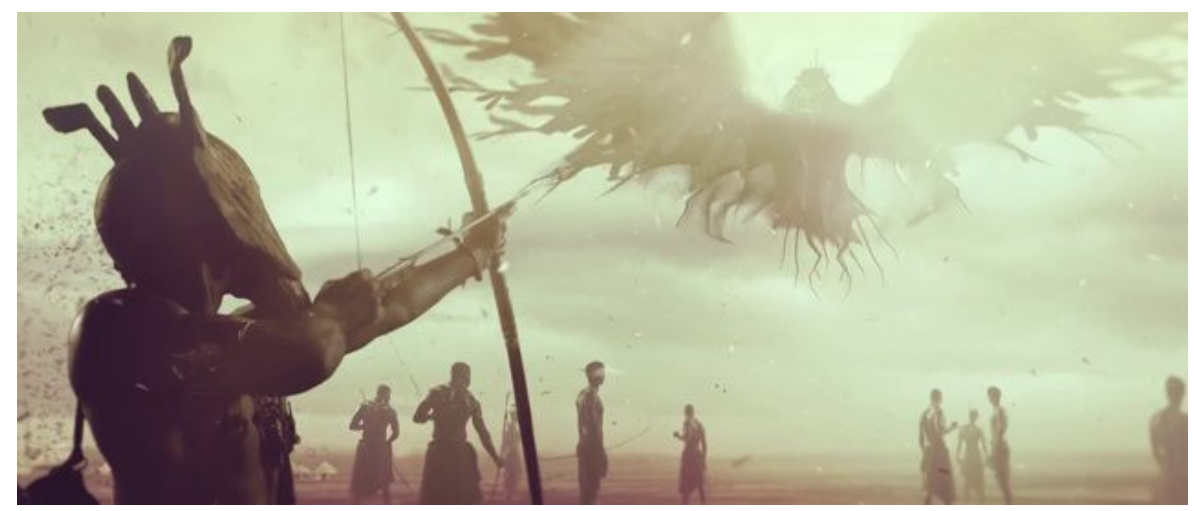

Fonte: https: //medium.com/ficcao-brasileira/deuses-de-dois-mundos-mitologia-africana-em-evidenciab61afb9187b9

\footnotetext{
${ }^{6}$ Disponível em: https://www.youtube.com/watch?v=GNAWuAlQKqE. Acesso em 6 nov. 2018.
} 
Figura 3 - Imagem do book trailer da trilogia

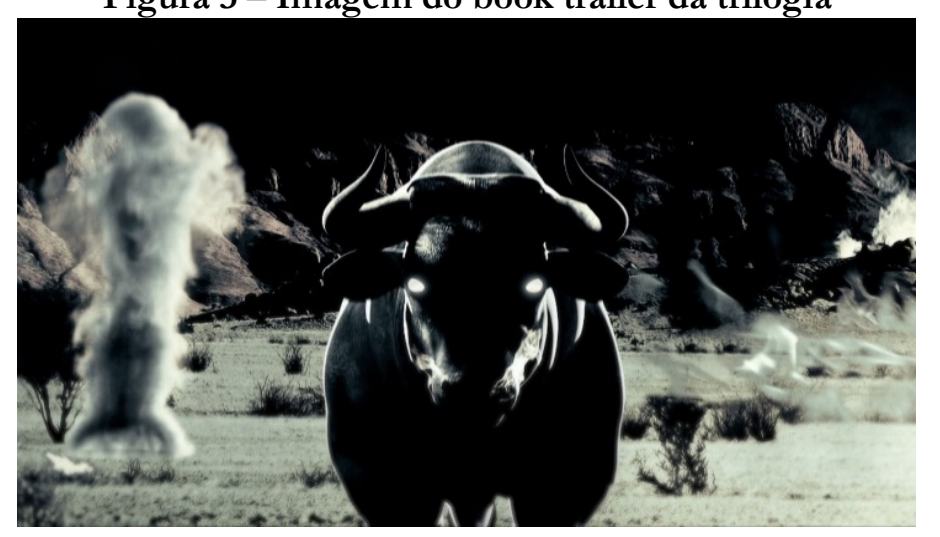

Fonte: https://zupi.co/deuses-de-dois-mundos-o-livro-da-morte/

As Figuras 1 e 2 referendam a luta de Orunmilá, o maior adivinho de todos os tempos, e seus guerreiros, os orixás, contra as Ia Mi Oxorongá, na busca pelo destino. As Iá Mi Oxorongá são conhecidas como mulheres pássaros, muito provavelmente a imagem do pássaro referencie elas. A Figura 3 referenda o mito de que Iansã se transforma em búfalo. Conjecturamos que o "silenciamento", ou a ausência de imagens que referendem diretamente o universo afrorreligioso, indica que o preconceito religioso impediria que um amplo público se aproximasse da obra casos esses elementos estivessem presentes.

Outra estratégia de publicidade utilizada na divulgação da mitologia foi a criação de uma página na internet ${ }^{7}$. Lá encontravam-se disponíveis o book trailer, já mencionado, informações de onde comprá-lo - com acesso direto para páginas de venda de seis livrarias, a sinopse, os primeiros dois capítulos dos primeiros dois volumes disponíveis gratuitamente para download, uma breve biografia do autor, agradecimentos e o acesso para a página do Facebook, mídia social criada para divulgação da obra, que obteve mais de 200 mil seguidores ${ }^{8}$.

Cada volume era vendido online no site da editora pelo valor de $\mathrm{R} \$ 40,00$, ou seja, a aquisição da trilogia custava $\mathrm{R} \$ 120,00$. No entanto, a partir do dia 29 de agosto de 2015, a obra foi disponibilizada integralmente para download gratuito."

Características dos volumes: capa: brochura; medidas: $16 \mathrm{~cm}$ x $23 \mathrm{~cm}$; volume 1 , O livro do silêncio: 264 páginas e 408 gramas; volume 2, O livro da traição: 384 páginas e 490 gramas; volume 3, O livro da morte: 344 páginas e 499 gramas. No índice para catálogo sistemático, inclui a indicação: Ficção, Literatura brasileira.

Analisamos os elementos existentes nas capas: presença de cores fortes, destaque do título e ilustração. Todas as capas foram criadas pelos mesmos profissionais: Paulo Coelho, Rafael Gil e

\footnotetext{
7 Em maio de 2019, o primeiro volume da trilogia também foi transformado em audiolivro. Narrado por Cintia Rosini e Chico Vinicius, com duração de $06 \mathrm{~h} 54 \mathrm{~m} 46 \mathrm{~s}$, o audiolivro foi produzido pela Tocalivros Studios e está sendo comercializado por R\$39,90. Disponível em: https://www.tocalivros.com/audiolivro/o-livro-do-silencio-pj-pereiracintia-rosini-chico-vinicius-editora-planeta?fbclid=IwAR1Bx04QLYkIHf2qmnq_xy2-

wnLo3qedNXIkvgC24w35WxGnAJWOPxl-NAA. Acesso em: 24 jun. 2018.

8 Disponível em https://www.facebook.com/DeusesdeDoisMundos. Acesso em 7 nov. 2018. Atualmente (em junho de 2019), a página intitulada Deuses de dois mundos, de PJ Pereira, divulga o livro mais recente do autor: $A$ mãe, a filha e o espírito da santa.

9 Disponível em https://downloadlivrospdf.wordpress.com/2015/08/29/deuses-de-dois-mundos_-vol-1_livro-dosilencio_pj-pereira/Acesso em 6 nov. 2018.
} 
Douglas Alves. No primeiro volume, sobressai a cor amarela de fundo, sobre a qual, em primeiro plano, a ilustração de um pássaro em voo, acertado por uma flecha. Conjecturamos que o pássaro represente as Iá Mi Oxorongá, mulheres pássaros que os orixás buscam vencer na luta pelo destino. A cor amarela, no candomblé, está intimamente associada a Oxum, mas, nesse caso, supomos que a escolha não teve essa intenção, visto que Oxum não tem qualquer destaque na obra. O título é o elemento central, sobreposto à imagem, Deuses de dois mundos escrito em branco, e abaixo, em fonte menor, O livro do silêncio, em amarelo-claro. O nome do autor é grafado em preto, acima da imagem, centralizado, na borda superior da capa, e o logotipo do selo da editora centralizado na borda inferior.

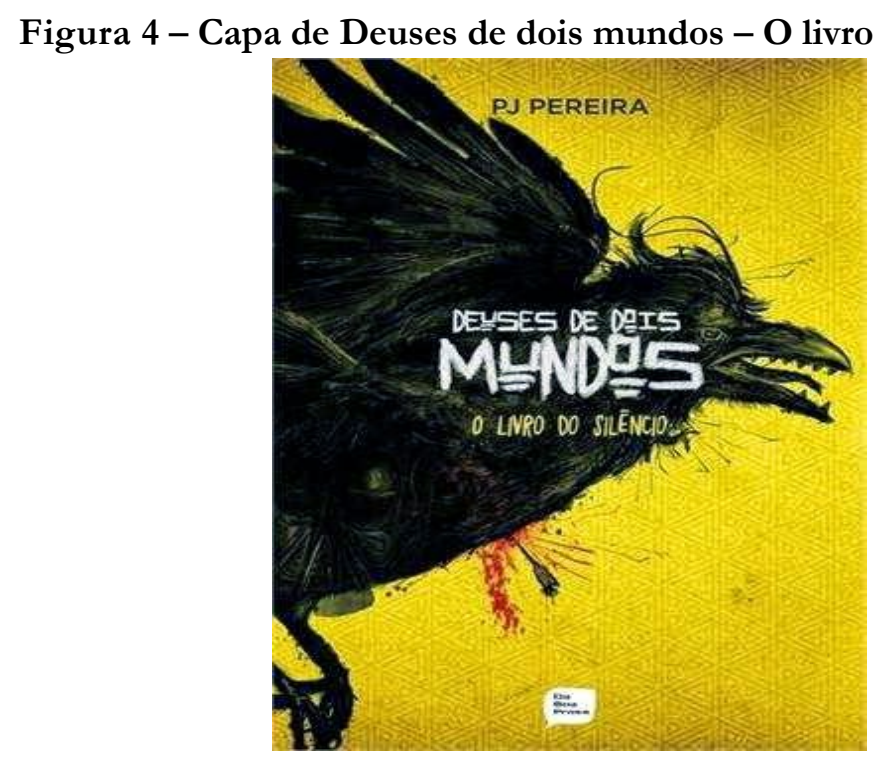

Fonte: https://www.saraiva.com.br/deuses-de-dois-mundos-o-livro-do-silencio-6206711.html

No segundo volume sobressai a cor vermelha; a ilustração, centralizada, parece de um pássaro morto, bastante ferido, o corpo retorcido, e de cabeça para baixo. O vermelho estaria associado a sangue ou guerra, elementos presentes nesse volume, como veremos adiante. Poderíamos supor que se tratasse da vitória dos orixás sobre as Iá Mi Oxorongá, na luta pela história dos homens; no entanto, nesse volume, elas não são vencidas pelos orixás, como a imagem daria a entender. Elemento central, sobreposto à imagem, o título Deuses de dois mundos escrito em branco, e abaixo, em fonte menor, O livro da traição, em amarelo-claro. $\mathrm{Na}$ borda superior da capa, o nome do autor centralizado, grafado em branco, sobrepõe parte da imagem escura; o logotipo do selo da editora é centralizado na borda inferior. 
Figura 5 - Capa de Deuses de dois mundos - O livro da traição

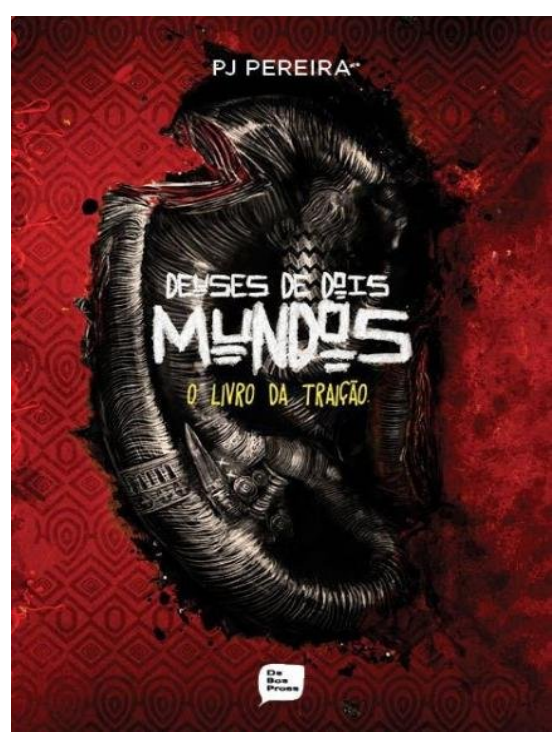

Fonte: https://www.livrariacultura.com.br/p/livros/literatura-nacional/ficcao-fantasiosa/deuses-de-doismundos-o-livro-da-traicao-capa-dura-42235971

No terceiro volume, sobressai a cor roxa e vemos a ilustração de uma caveira. O roxo no candomblé normalmente está associado ao orixá feminino Nanã, a divindade que tem regência sobre a morte. Mas não é possível afirmar que a escolha da cor e da imagem para a capa desse volume seja em referência a ela. Dessa vez, o título sobrepõe a imagem na porção inferior da capa; Deuses de dois mundos escrito em branco, e abaixo, em fonte menor, O livro da traição, em lilás. O nome do autor, grafado em branco, no topo do crâneo, se confunde com a imagem; na borda oposta, o logotipo do selo da editora centralizado.

Figura 6 - Capa de Deuses de dois mundos - O livro da morte

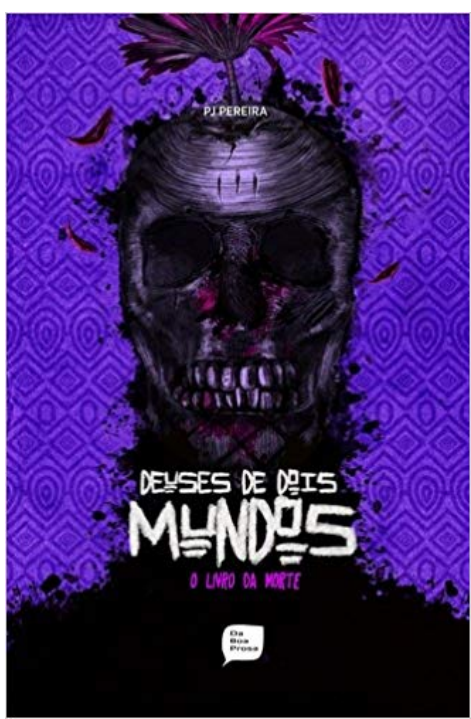

Fonte: https://www.amazon.com.br/Deuses-Dois-Mundos-Livro-Morte/dp/8564684594 
Nesse sentido, destacamos os apontamentos de Sandra Pesavento (2008), para quem as imagens são construções que se constituem a partir de diferentes suportes e com múltiplos objetivos.

As imagens são, e têm sido sempre, um tipo de linguagem, ou seja, atestam uma intenção de comunicar, que é dotada de um sentido e é produzida a partir de uma intenção humana intencional. E nessa medida, as imagens partilham com as outras formas de linguagem a condição de serem simbólicas, isto é, são portadoras de significados para além daquilo que é mostrado (PESAVENTO, 2008, p. 99).

Considerando que as imagens tenham um estatuto próprio e se constituem enquanto representações com sentido e com uma intenção, atentamo-nos para a expectativa em relação à recepção do espectador. Se a criação ou divulgação de uma imagem implica reconhecer um destinatário, compreendemos que PJ Pereira não visava necessariamente atingir o público candomblecista, porque não escolheu representações imagéticas que fizessem parte do seu "museu imaginário" (PESAVENTO, 2008). Inclusive, é relevante assinalar que nenhuma das capas apresentam imagens ou elementos do culto africano, ou afro-brasileiro, aos orixás. É possível que o autor tenha se preocupado com o modo que seus leitores associariam essas imagens a discursos negativos e pejorativos que são difundidos em diversos canais, principalmente midiáticos, sobre as crenças afro-brasileiras.

Esse silenciamento em relação aos elementos afro-brasileiros mais controversos, ou de menor aceitação social, pode estar inserido nesse processo histórico de naturalização do branqueamento e, portanto, da colonialidade. Evocamos Krada Kilomba (2019), teórica e artista decolonial, para compor essa problematização conosco. Em Memórias da plantação: episódios de racismo cotidiano, ela utiliza a metáfora da máscara de Anastácia para apontar a perversidade colonialista, na qual o sujeito universal domina e emudece aqueles os quais determina como o outro, a partir do seu sistema mundo colonial-patriarcal - racializado, heteronormativo e capitalista. Conforme a autora, a máscara não é somente um instrumento de tortura, mas ferramenta que tem como fim o controle, a mudez, a não-fala. Não diz respeito apenas ao silêncio, mas ao poder de determinar o silenciamento forçado.

Assim, partimos do pressuposto de que a instauração do poder colonial causa uma fratura, em que a linguagem e a cultura são instituídas como lugares nos quais operam essas lógicas de poder. Nesse contexto, a linguagem e a cultura do "sujeito de cor" são significadas como selvagens e, portanto, tornam-se alvo da domesticação e silenciamento. A teórica chicana Glória Anzaldua (2009), aponta justamente esse esforço em "domar uma língua selvagem" como um recurso masculino, branco, utilizado para fins de controle e dominação. Conforme a autora, a cultura e a linguagem são centrais nas disputas pelo direito de significar o mundo e, nessa arena, a linguagem do homem branco colonizador objetiva controlar, domar, aparar e limitar o que determina como o outro. Desse modo, o silenciamento é considerado um esforço colonizador de decepar e arrancar as raízes culturais e linguísticas de populações não hegemônicas. Essa discussão torna-se relevante nesse trabalho, para problematizarmos as escolhas operadas pelo autor da nossa fonte. Visto que, por vezes, elas resultam no silenciamento de importantes valores civilizatórios afro-brasileiros.

É possível que as imagens macabras, sobretudo a da caveira - no terceiro volume -, a estética não realista e a valorização das cores marcantes tenham como destinatário o público adolescente e juvenil que PJ Pereira aponta representar metade dos seus leitores. 
[...] a imagem é portadora de significados que são construídos e ou descobertos por aquele que pensa enquanto olha... Da visão ao olhar - que constitui o ver, mas estabelecendo significados e correlações -, uma operação mental introduzisse. Nessa instância da percepção, a imagem visual será complementada por uma imagem mental, que classifica, qualifica e confere sentidos àquilo que é visto (PESAVENTO, 2008, p. 101).

No primeiro volume, ainda consta a sinopse da obra na primeira orelha, e uma minibiografia do autor, na segunda. E o posfácio escrito pelo sociólogo Reginaldo Prandi.

Na mitologia dos iorubas, um dos povos africanos dos quais traficantes roubaram homens, mulheres e crianças para trazer para o Brasil como escravos, deuses e humanos um dia viveram juntos. Até que dois desses deuses brigaram e criaram a separação entre o Orum (que chamamos de Céu) e o Aiê (Terra). Ao construir Deuses de dois mundos - o livro do silêncio, PJ Pereira põe a mitologia de cabeça para baixo, juntando de novo humanos e deuses num mesmo cotidiano, fundindo mito e ficção, recriando um universo em que os ciclos da repetição são rompidos e substituídos pelo produto da imaginação do autor, que, no entanto, os faz voltar em seguida ao movimento original. Em termos mitológicos esse jogo poderia resultar numa catástrofe como a que dividiu o mundo em dois, mas para nossa sorte o que a inversão operada por PJ Pereira pretende e consegue é produzir um livro delicioso de se ler, um 'livro do silêncio', que é capaz, contraditoriamente, de nos falar bem alto, como gosta a boa mitologia (PRANDI apud PJ PEREIRA, 2013, p. 245-246).

As folhas de guarda apresentam a ilustração de um olho, e a ilustração do território ioruba em preto e branco. Acreditamos que a imagem do território ioruba busque facilitar a compreensão do leitor em relação às viagens relatadas dos orixás e de Orunmilá, de uma região a outra do território ioruba, em busca dos odus capturados. A imagem do olho nos lembra a expressão "O olho que tudo vê". Essa expressão não é utilizada no livro, por isso não é possível dizer a intencionalidade dessa imagem com exatidão, mas nos remeteu a Exu, a divindade que está em todos os caminhos, e sabe de tudo. A folha de rosto contém somente o título da obra e no verso encontram-se os dados de catalogação do livro. $\mathrm{Na}$ folha seguinte encontramos uma frase de Pierre Verger sobre os orixás e, na outra, o sumário, que apresenta a disposição dos capítulos. Em seguida, já encontramos o prólogo que inicia a narrativa.

Figuras 7 e 8 - Folhas de guarda de Deuses de dois mundos - O livro do silêncio

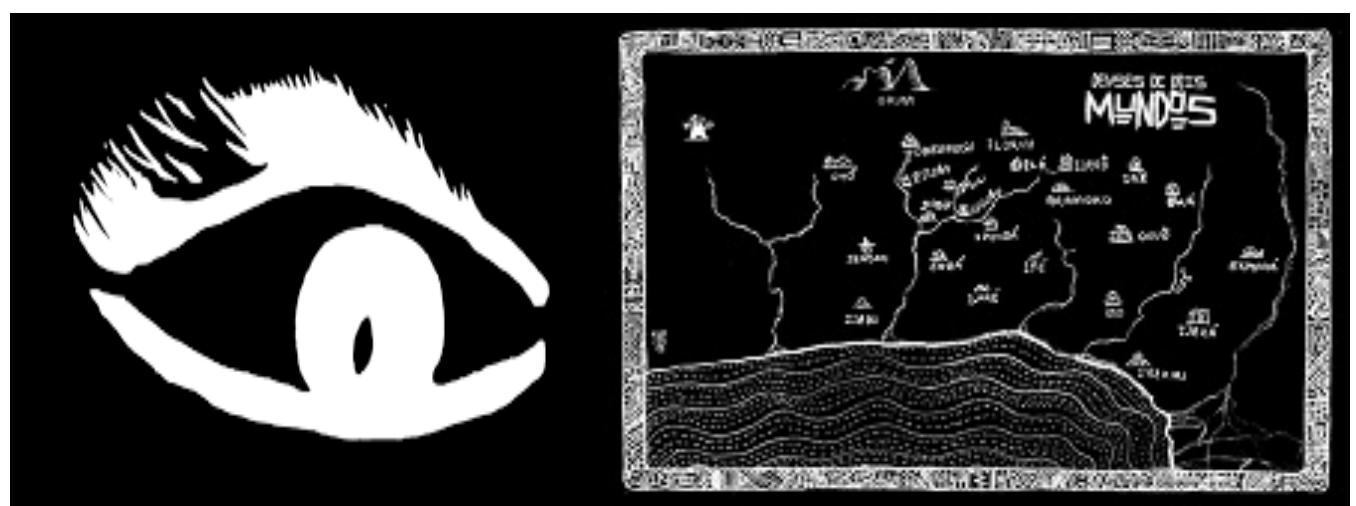

Fonte: http://www.leremais.com.br/2015/07/resenha-79-deuses-de-dois-mundos-o.html 
A estrutura do livro intercala os capítulos em que Newton Fernandes, o protagonista, se comunica com Laroiê (Exu), por e-mail, narrando os acontecimentos que se passam no aiê, mundo dos humanos, e os capítulos que narram as aventuras dos orixás no orum, mundo dos orixás. São 15 e-mails e outros 15 capítulos que narram o mundo dos deuses. A primeira mensagem publicada pelo protagonista, por meio da conta NewFernandes@hotmail.com, tem como assunto o nome "Pedido de ajuda" e inicia-se com a descrição: A quem interessar possa. Todos os outros e-mails são direcionados diretamente para Laroiê, com o título Pedido de ajuda e o número correspondente da mensagem ${ }^{10}$. Todos os e-mails são finalizados com os dizeres: Axé, New, seguidos do local e data da mensagem. Os outros capítulos têm títulos que dizem respeito ao acontecimento marcante do capítulo. É dessa forma que os capítulos se organizam.

Ao fim da narrativa, encontramos o epílogo, o posfácio, que apresenta alguns aspectos da mitologia dos orixás - escrito por Prandi, um glossário de termos africanos, contendo dezoito palavras, agradecimentos do autor, alguns trechos do segundo volume e uma homenagem aos fãs da obra. Trata-se de uma montagem contendo 114 fotos de pessoas em posse do primeiro volume da trilogia.

No segundo volume, O livro da traição, também há uma sinopse na primeira orelha e, na segunda, o mesmo resumo sobre a vida do autor. As folhas de guarda são as mesmas do primeiro volume. A folha de rosto tem o mesmo formato e informações referentes aos dados de catalogação do primeiro livro. $\mathrm{Na}$ folha seguinte, encontramos uma frase de Nelson Rodrigues e, na próxima, o sumário, que apresenta a disposição dos capítulos. Na sequência, encontramos o prefácio do autor, o qual apresenta brevemente aspectos da mitologia dos orixás, apresenta os protagonistas da trama e retoma brevemente a narrativa do primeiro livro. Em seguida, vem o prólogo e repete-se a estrutura do primeiro volume, intercalando os e-mails de Newton Fernandes e os capítulos que narram a história dos deuses.

São 17 e-mails que narram a vida do protagonista na terra e 18 capítulos que contam a história dos deuses na África ancestral. Ao fim, encontramos o epílogo e o posfácio e um glossário com 78 termos em ioruba e seus significados em português. Também constam agradecimentos e uma homenagem aos fãs, uma montagem contendo quarenta fotos de pessoas portando $O$ livro da morte.

O terceiro volume, O livro da morte, também tem orelha com a sinopse, demonstrando como é possível ler os livros da trilogia de forma independente. Também apresenta brevemente a biografia do autor e elogia o trabalho que ele realiza na trilogia, com os dizeres:

Ele foi quase um mestre ao respeitar as tradições da religião sem descanso em pesquisas e conversas sobre histórias originadas de mitos e lendas e sem temer apresentá-las de uma forma original, como se a forma do novo encaixe já existisse num outro tempo, PJ Pereira criou um universo, ele resgata uma parte linda do Brasil e a reapresenta a todos nós, dos mais diferentes credos, e está sendo exportada, vai ser um cartão postal da nossa diversidade e riqueza. Deuses de dois mundos vai mostrar aos vários cantos do planeta Terra que histórias tão boas quanto $\mathrm{O}$ senhor dos Anéis, A guerra dos tronos, e tantas outras, também surgem por aqui.

As folhas de guarda são outras, mas do mesmo ilustrador, Moses Kelani, uma referenda o orum e o aiê, demonstrando a geografia mítica ioruba e a outra referenda o vínculo entre um iniciado

${ }^{10}$ Exemplo: Resposta (3): Pedido de ajuda. E-mail seguinte: Resposta (5): Pedido de ajuda. 
e o seu orixá. Trata-se de uma noção bastante presente na trilogia, de uma ligação que se dá entre a cabeça do neófito e o umbigo da divindade. A folha de rosto possui o mesmo formato e informações referentes aos dados de catalogação do segundo livro. $\mathrm{Na}$ folha seguinte, encontramos um ditado ioruba: "[...] Exu matou um pássaro ontem, com uma pedra que somente hoje atirou". Em seguida, encontramos o sumário e, na folha seguinte, o prefácio, escrito por Marcelo Tás (ator e apresentador de televisão):

O preconceito é o combustível da violência contemporânea. A ignorância é a faísca que detona barbáries como o 11 de Setembro e o ataque aos cartunistas do Charlie Hebdo. No DNA da violência bruta, o medo. Sim, o preconceito nasce do medo do desconhecido e invade os terrenos férteis da insanidade como plantas vorazes espalhando o pólen da intolerância e do fundamentalismo. $\mathrm{O}$ livro que você tem em mãos nasceu do preconceito. O próprio autor é quem diz. Diante do preconceito que tinha das religiões africanas, PJ Pereira se jogou num mergulho de 15 anos de pesquisa da história do povo Ioruba, um dos maiores grupos étnicos-linguísticos do Continente Negro. Descobriu não um, mas dois mundos. Daí o título da vigorosa trilogia, Deuses de Dois Mundos, DDDM para os íntimos. Uma terra sem tempo, onde a história anda em círculos, habitada por deuses chamados orixás em luta permanente por controle, equilíbrio e harmonia. Para a travessia, PJ enfrentou o fantasma do medo com a palavra coragem que, ao contrário da contração fundamentalista, significa abrir o coração. Que cada um de nós se inspire no PJ para transformar preconceito em storytelling. Que coisa mais linda, parir um livro como resposta ao preconceito. Eis a saída para o fundamentalismo galopante dos nossos dias e a porta de entrada para a nova civilização que tanto queremos. Axé!!! (MARCELO TÁS apud PJ PEREIRA, 2015, p. 15).

Figuras 9 e 10 - Folhas de guarda de Deuses de dois mundos - O livro da morte

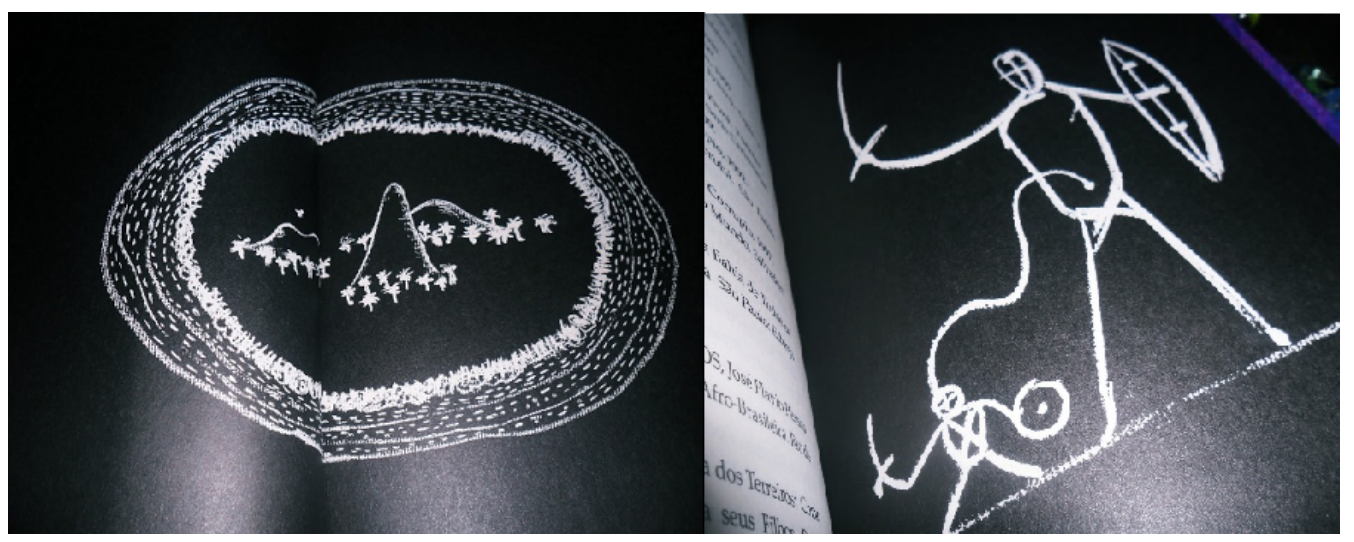

Fonte: http://vanessanonatoo.blogspot.com/2015/08/resenha-deuses-de-dois-mundos-o-livro_28.html

Nas três próximas páginas, o autor apresenta um resumo breve dos primeiros volumes, para localizar os leitores que não tiveram acesso a eles. É explicado como se organizam os capítulos e dito que, diferente dos volumes anteriores, neste livro a conversa entre Newton e Laroiê não acontece por e-mail, mas na forma de um blog, e como tal, será lido de trás pra frente. As primeiras mensagens sendo as últimas a serem escritas. Na sequência, encontramos o prólogo e já se inicia a narrativa. Os capítulos ímpares acontecem no orum (mundo dos orixás), são 17 no total e todos 
têm como título o nome de divindades iorubas, tais como Euá, Nanã, Iansã, Xangô, Obá, Iemanjá, etc.

Os capítulos pares são dedicados ao mundo do aiê (a Terra, o mundo dos humanos), são 16 no total e os títulos fazem referência aos acontecimentos presentes nele, como "Minha morte", "Cabeça feita", etc. Ao final, vêm o Epílogo e o Posfácio do autor, no qual ele fala sobre o desafio de construir a narrativa, da perspectiva essencialmente masculina, que mantinha os dois primeiros volumes, para, no terceiro, mostrar algo novo, ou seja, a luta das mulheres pelo controle do destino:

[...] imaginavam que essa visão distorcida fazia parte da mitologia e eu estava apenas respeitando a tradição. Eu estava, em parte. Na guerra dos orixás, um assunto importante e recorrente na mitologia Ioruba, eu optei por começar machista para poder evidenciar o nosso próprio preconceito (ou a aceitação dele) na chegada do livro três, quando o equilíbrio finalmente se reestabelece. Preconceito, aliás, é um dos tons mais importantes dessa obra, desde sua concepção. Comecei a escrever para me confrontar com meu medo das religiões africanas, especialmente da figura de Exu, que mais tarde virou meu personagem predileto. Não me surpreende, portanto, que entre milhares de mensagens que eu recebi online, tantas tenham me acusado de satanismo e me sentenciado ao inferno. O trailer do meu livro teve inclusive uma cena roubada para promover uma outra obra religiosa que associava orixás a demônios. O que eu não esperava foi que em reação a esse fanatismo de alguns setores evangélicos, grupo mais vocal entre os críticos, também viesse um outro conjunto de pessoas da mesma religião, gritando em minha defesa. [...] Igualmente encantador foi que essa discussão também serviu para demonstrar que a ignorância dos neopentecostais é limitada a uma parte deles apenas (PJ PEREIRA, 2015, p. 327).

O posfácio, intitulado "Alterador de Consciência DDDM", foi escrito pelo jornalista e apresentador de televisão Arthur Veríssimo. Ele menciona que explorou, durante trinta anos de sua vida, diversas experiências religiosas por toda a América Latina, por isso não se impressiona facilmente. Mesmo assim, se sensibilizou com a obra por sua força, estilo textual, e por criar um caminho entre o sagrado e o profano. Veríssimo assinala que:

Em O livro da morte, PJ Pereira terminou seu trabalho como o Alagbé, o supremo maestro dos atabaques na criação desta trilogia, o criador deste imã que atrai leitores de todas as castas e credos, como se fossem partículas de ferro encantadas pelo campo magnético que é o DDDM. Neste grand finale, a imprevisibilidade e experimentalismo do texto desafiaram o leitor a reconstruir e ler os relatos com destemida atenção [...] Em seu caleidoscópio mitológico e suas revelações progressivas, as lendas, rituais, cerimônias, segredos e mistérios do universo dos orixás saltaram diante dos nossos olhos e se multiplicaram neste derradeiro romance mitológico-policial-espiritual-político. A escritura como transliteração da fala e dos mitos. A fruição do texto. A linguagem frenética seduz e fere. Tomamos conhecimento dos poderes dos orixás. Somos apresentados, finalmente, ao ponto de vista das Iá Mi Oxorongá, cuja força revolucionária e paciente já vinha borbulhando como néctar por toda a obra. Ligando esses dois mundos está o orixá Exu (Laroiê). Figura nevrálgica no emaranhado de personagens, é difícil não perceber suas semelhanças com deuses como Ganesh do panteão hindu e Hermes do panteão grego [...] Mais que qualquer outro, é Exu que carrega essa mitologia muito além de um grupo particular de religiões 
de origem africana e faz com que essa história se torne universal (ARTHUR VERÍSSIMO apud PJ PEREIRA, 2015, p. 327, 328, 329).

Em seguida, PJ Pereira faz os agradecimentos e inclui a bibliografia utilizada em sua pesquisa para a escrita dos três volumes. O autor menciona que está apresentando as fontes a pedido do público, mas também conjecturamos que ele as indique como forma de obter maior autoridade sobre sua própria narrativa. Ao observarmos as suas referências, notamos que o autor se apropriou da literatura científica sobre as religiões afro-brasileiras, mitos africanos e liturgia no culto ao orixá, para a criação da narrativa ficcional. Isso não quer dizer que o autor tenha reproduzido essa literatura de modo imparcial.

São 85 obras citadas nessa bibliografia e somente 16 delas não são literatura científica. Vinte e duas são referências em inglês, duas em espanhol e uma em francês. Vinte e três abordam, principalmente, o candomblé e culto aos orixás no Brasil; dezesseis tratam, principalmente, de provérbios, mitos e orikis africanos; quinze se referem, principalmente, ao culto dos orixás na África; seis delas são biografias, uma é de Nelson Rodrigues, as outras de lideranças religiosas do Brasil, como Mãe Menininha e Mãe Senhora; cinco delas são de temática ligadas a outros cultos, religiosidades e sociedades secretas; quatro delas se referem ao culto dos orixás em outros países, como Cuba e Haiti; quatro remetem à função social do mito; quatro versam sobre arte africana; três são relacionadas ao fazer jornalístico; duas são obras literárias, uma de ficção sobre o cotidiano, de Nelson Rodrigues, e a outra de ficção ligada à religiosidade africana; uma se refere ao estudo sobre os animais; e, por fim, uma que trata da filosofia ioruba.

Os capítulos dedicados ao mundo do aiê foram publicados na página do Facebook criada para o personagem Newton Fernandes, semanalmente, às segundas-feiras, dia consagrado a Exu, no candomblé. Esse espaço foi criado para o público interagir com o autor e outros leitores da obra. "[...] Como essa parte do livro foi escrita em formato de posts, achei que seria bom os leitores poderem experimentar isso na plataforma original ${ }^{11 "}$, conta PJ Pereira (2015). A adaptação do conteúdo do livro para publicação no Facebook foi feita por Bernardo Ratto, que coordenou o projeto junto com Marcelo Freitas ${ }^{12}$. Para o autor, essa estratégia foi bastante eficiente para a divulgação da trilogia. "[...] Foi o boca a boca nas redes sociais que garantiu o espaço de Deuses de dois mundos na fila de leitura das pessoas. Foi nas mídias sociais que o livro se fez. Algumas pessoas até reclamavam que queriam ler o livro, mas não o encontravam nas livrarias ${ }^{13}$."

Destacamos também que a obra foi distribuída em versão digital (e-book), foi traduzida para língua inglesa e teve os direitos de adaptação para cinema, quadrinhos e televisão vendidos para a The Alchemists, produtora de seriados como Smallville e Heroes ${ }^{14}$. A trilogia vendeu cerca de 50 mil exemplares, número considerável para um mercado que celebra quando tiragens de 3 mil se esgotam. Foi a obra mais vendida do selo Da Boa Prosa, da Editora Livros de Safra. Além disso, ocupou o ranking dos livros mais vendidos do país. Em 2015, estava entre os quatro mais vendidos na pesquisa da revista $V e j a$, - sendo a obra de ficção mais vendida do país durante algumas semanas - e em sexto lugar nas pesquisas de O Globo e da Folha de S.Paulo ${ }^{15}$.

\footnotetext{
${ }_{11}$ Disponível em http://www.clubedecriacao.com.br/ultimas/o-livro-da-morte/. Acesso em 9 nov. 2018.

12 Idem.

13 Disponível em https://veja.abril.com.br/entretenimento/brasileiro-desafia-best-sellers-americanos-com-seriesobre-orixas/. Acesso em 9 nov. 2018.

14 Disponível em https://adnews.co/m.br/internet/o-livro-da-morte-tera-metade-do-conteudo-/publicado-nofacebook/. Acesso em 8 nov. 2018.

${ }^{15}$ Disponível em http://www.livrosdesafra.com.br/tag/deuses-de-dois-mundos/. Acesso em 9 nov. 2018.
} 
Em entrevista para Meire Kusumoto (2015), da revista $V e j a$, em 31 de maio de 2015, PJ Pereira comenta que metade dos seus leitores são entusiastas de literatura fantástica, outra metade lê seus livros por influência religiosa, e que:

A trilogia também pode ter sido impulsionada pelo boom da literatura fantástica no Brasil e no mundo, que viu nascer fenômenos como Harry Potter, de JK Rowling, Percy Jackson \& os Olimpianos, de Rick Riordan, e As Crônicas de Gelo e Fogo, de George R.R. Martin, base da série de sucesso da HBO Game of Thrones.

O lançamento do terceiro livro, realizado em São Paulo, no dia 11 de maio de 2015, reuniu centenas de fãs da trilogia para sessão de autógrafos em uma fila que se manteve após o fechamento da Livraria Cultura, no Conjunto Nacional. Acrescidos aos fatos que citamos anteriormente, demonstramos que a trilogia inspirada na mitologia ioruba obteve espaço nas livrarias brasileiras, apesar de ter sido recusada por algumas editoras dez anos antes, sob o argumento de que não havia mercado para este tipo de literatura no Brasil (BAOBÁ, 2015). Além disso, a trilogia foi considerada pela crítica uma obra literária envolvente que busca combater o preconceito e difundir a cultura afro-brasileira. A obra também recebeu o prêmio Luiza Bairros pela contribuição à cultura africana no Brasil.

\section{CONSIDERAÇÕES FINAIS}

Em nossa perspectiva, as práticas afrorreligiosas apropriadas e ressignificadas por PJ Pereira foram representadqs de maneira bastante ocidentalizada. Muitas vezes, os mitos perderam suas principais características e questionamentos filosóficos. Em diversas composições, como mencionamos acima, houve uma tentativa do autor de torná-los mais palatáveis. Acreditamos que esse foi o modo que PJ Pereira (2015) encontrou de tornar a narrativa inteligível para todos os seus leitores, e não somente para os adeptos do candomblé ou conhecedores de seus mitos. Em busca de um pretenso universalismo eurocêntrico, de um modo único e racional de pensar, as complexidades e conflitos que incidem nas representações mais controversas das divindades são silenciadas ou escamoteadas para serem socialmente aceitas (SPIVAK, 2010; FANON, 2008; MOHANTY, 1991).

No entanto, uma vez que o autor se afasta das representações tradicionais, que associamos aqui à "negritude", se distancia daqueles que estão à margem dos processos de globalização e seus efeitos de comunicação. Compreendemos que é no interior da circularidade de enunciados que as influências de representações também circulam e interagem com as estruturas que as modelam e por elas são modeladas. As práticas afrorreligiosas ainda estão no centro de um tensionamento entre as noções de ruptura e preservação de um projeto baseado ainda no embranquecimento cultural, na ocidentalização do saber, na ocidentalização da alteridade, da informação e do conhecimento (FANON, 2008; SPIVAK, 2010; MOHANTY, 1991).

Como aponta Stuart Hall (2006), não é a permanência ou o declínio das identidades culturais que devem ser colocadas em evidência, mas o questionamento das reinterpretações dessas identidades diante das transformações radicais dos sistemas de representação, que correspondem à volatilidade do capital cultural, à construção do mercado de bens culturais e à homogeneização cultural. Nesse sentido, compreendemos que, para tornar os orixás protagonistas de um best-seller, foi preciso embranquecer, suavizar e silenciar alguns de seus aspectos controversos. Quem tem autoridade para isso é um sujeito branco de classe média, não religioso. 
Do ponto de vista teórico, concluímos que o ensino de história que queira realizar, de fato, o previsto na Lei 10.639/03, precisa ser capaz de reconhecer que as divindades das populações negras quase não têm espaço na disputa legítima por dignidade e reconhecimento, mas quando existe um porta-vOz que enquadra esses deuses nos modos de civilidade do status quo, essas divindades começam a aparecer na televisão, no cinema, no rádio e nas teorias científicas, refletimos sobre a lógica colonial ${ }^{16}$, que trabalha sob sua própria cognição e gramática. Essa, historicamente, intencionou o desbarate e o comércio dos bens simbólicos de povos subjugados. Em nossa visão, é importante que olhemos com cuidado para as apropriações que homens brancos têm forjado sobre a cultura afro-brasileira. Refletir sobre o racismo ${ }^{17} \mathrm{em}$ suas múltiplas esferas, inclusive na ordem do conhecimento e sua intercessão com o capital, é refletir sobre como bens simbólicos afro-brasileiros são legitimados e autorizados quando agenciados por homens brancos. Por isso, a importância de confrontar os fetiches produzidos em torno das sabedorias africanas e afrobrasileiras.

Acenamos para a ideia de que os discursos que tangem a cultura negra e que não nascem no seu interior produzem uma diferença. Conforme Mohanty (1991), é na produção dessa diferença que esses discursos "colonizam" as complexidades e conflitos que caracterizam as práticas e códigos compartilhados dessa cultura. A reflexão da autora sugere que a produção de descrédito e invisibilidade de alguns grupos em detrimento de outros é uma estratégia para a manutenção da autoridade e do direito de representar a todos como sujeitos universais. Outra discussão importante está presente na obra Peles negras, máscaras brancas, de Frantz Fanon (2008), que também reflete sobre a "colonização epistemológica" e o "embranquecimento cultural". Psiquiatra e pensador de ascendência africana, Fanon demonstra, nesse livro, que a colonização não se limita à subjugação material de um povo, ela opera também por mecanismos políticos e ideológicos que hierarquizam os seres humanos e as diferentes culturas. Ele defende que a luta contra a opressão no mundo colonial deve abranger o conjunto das esferas em que a opressão se manifesta, considerando fatores psicológicos, contexto histórico e social, sistema político e econômico. O pesquisador postula que é preciso descolonizar as nações, mas sobretudo os seres humanos. Conforme o autor, descolonizar consiste em forjar sujeitos novos, modificar fundamentalmente o ser, transformar espectadores em atores da história.

Muitos outros autores que se utilizam dos elementos presentes nas religiões afro-brasileiras para a criação de narrativas literária e atendem ao público infanto-juvenil poderiam ser citados, como Hugo Canuto, Marcelo D’Salete e Robson Moura. Elegemos neste artigo a obra Deuses de dois mundo pois ela nos dá condições de refletir justamente sobre o universo simbólico afrobrasileiro como território de contínuas e complexas disputas culturais, sociais e políticas.

\section{REFERÊNCIAS}

ANZALDÚA, Gloria E. Como domar uma língua selvagem. Tradução Joana Plaza Pinto e Karla Cristina dos Santos. Revisão da Tradução Viviane Veras. Cadernos de Letras da UFF, Dossiê: Difusão da Língua Portuguesa, Rio de Janeiro, n. 39, p. 297-309, 2009.

\footnotetext{
16 Estamos falando sobre a lógica colonial, a partir da teoria crítica pós-colonial. Conforme Aníbal Quijano (2000), trata-se das relações intersubjetivas de dominação pautadas numa hegemonia eurocêntrica, reproduzindo um padrão de poder que se baseia numa perspectiva de mundo descendente da imposição da visão europeia, tratando o racionalismo e a objetividade como valores absolutos. Dessa forma, constitui-se o "sistema moderno-colonial".

17 Nos ancoramos em Miles e Brow (2004), para pensar o racismo como um fenômeno estrutural, ideológico e discursivo, que se expressa nas leis, políticas públicas e práticas padronizadas que subordinam grupos racializados.
} 
ARAÚJO, Joel Zito. A força de um desejo - a persistência da branquitude como padrão estético audiovisual. In: Revista USP, São Paulo, n. 79, 2006

BAOBÁ Comunicações. Deuses de dois mundos - O livro da morte. Da trilogia inspirada na mitologia ioruba é o mais vendido. 27 maio 2015. Geledés. Disponível em https://www.geledes.org.br/deuses-de-dois-mundos-o-livro-da-morte-da-trilogia-inspirada-namitologia-ioruba-e-o-mais-vendidos/ Acesso em 8 nov. 2018.

BRASIL. Lei n. 10.639, de 9 de janeiro de 2003. Altera a Lei n. 9.394, de 20 de dezembro de 1996, que estabelece as diretrizes e bases da educação nacional, para incluir no currículo oficial da Rede de Ensino a obrigatoriedade da temática "História e Cultura Afro-Brasileira", e dá outras providências. Diário Oficial da União, 10 de janeiro de 2003. Brasília, DF: Presidência da República, 2003.

CASTRO, Yeda Pessoa de. Falares africanos na Babia: um vocabulário afro-brasileiro. Rio de Janeiro: Topbooks, 2001.

CHARTIER, Roger. Cultura Popular: revisitando um conceito historiográfico. Estudos Históricos, v. 8, n. 16, p. 179-192, 1995.

CHARTIER, Roger. Os desafios da escrita. São Paulo: Ed. Unesp, 2002.

CUNHA, Carolina. Série de fantasia faz sucesso ao mostrar o mundo dos orixás. Entrevista com PJ PEREIRA. Saraiva Conteúdo, 29 jul. 2014. Disponível em https://blog.saraiva.com.br/serie-defantasia-faz-sucesso-ao-mostrar-o-mundo-dos-orixas/. Acesso em 4 jun. 2018.

FANON, Frantz. Pele negra, mascaras brancas. Salvador, Edufba, 2008.

GOMES, Nilma Lino. Movimento negro e educação: ressignificando e politizando a raça. Educação \& Sociedade [online], v. 33, n. 120, p. 727-744, 2012.

GONÇALVES, Leonardo de Oliveira. Lei federal n 10.639/03: um desafio para a educação básica no Brasil. Dissertação (Mestrado em Educação), Universidade Católica de Santos, São Paulo, 2010. KILOMBA, Grada. Memórias da plantação: episódios de racismo cotidiano. Tradução Jess Oliveira. 1. Ed. Rio de Janeiro: Cobogó, 2019

KUSUMOTO, Meire. Brasileiro desafia best-sellers americanos com série sobre orixás. Veja, 31 maio 2015. Disponível em https://veja.abril.com.br/entretenimento/brasileiro-desafia-bestsellers-americanos-com-serie-sobre-orixas. Acesso em 8 nov. 2018.

LEÃO, Gabriel. Os livros com os orixás: uma entrevista com PJ Pereira. Vice, 2 jan. 2015. Disponível em https://www.vice.com/pt br/article/ypm5k7/os-livros-com-os-orixasumaentrevista-com-pj-pereira. Acesso em 4 out. 2018.

LIMA, Identidades e africanidades: uma perspectiva para a educação. In: GOMES, Carlos Magno; ENNES, Marcelo Alario (org.). Identidades: teoria e prática. São Cristóvão: Editora UFS, 2008.

MOHANTY, Chandra T. Under western eyes: feminist scholarship and colonial discourses. In: MOHANTY, Chandra T.; RUSSO, Ann; TORRES, Lourdes (eds.). Third World women and the politics of feminism. Bloomington: Indiana University Press, 1991.

PACHECO, Paula. PJ Pereira, o publicitário que mergulhou na mitologia dos orixás. $i G-$ Brasil Econômico. 5 dez. 2013. Disponível em https://economia.ig.com.br/2013-12-03/pj-pereira-opublicitario-que-mergulhou-na-mitologia-dos-orixas.html. Acesso em 4 jun. 2019.

PESAVENTO, Sandra Jatahy. História \& história cultural. 2. ed., Belo Horizonte: Autêntica, 2008 [2003]. 
PESAVENTO, S. História \& literatura: uma velha-nova história. Nuevo Mundo Mundos Nuevos [Em línea], De bates, 2006. Disponível em http://nuevomundo.revues.org/1560. Acesso em 20 jun. 2019.

PRANDI, Reginaldo. Mitologia dos orixás. São Paulo, Companhia das Letras, 2001.

QUIJANO, Aníbal. Colonialidad del poder y clasificación social [homenagem a Immanuel Wallerstein], part I. Journal of World Systems Research, v. XI, n. 2, 2000.

ROSA, José Antônio. Análise do livro como produto e como negócio no contexto brasileiro atual: referências para a estratégia de marketing e comunicação na indústria editorial e para decisões de fomento e difusão do livro no âmbito governamental e institucional. Tese (Doutorado em Ciências da Comunicação), Escola de Comunicação e Artes, Universidade de São Paulo, São Paulo, 2008.

SAMARA, Timothy. Grid: construção e desconstrução. São Paulo: Cosac Naify, 2007.

SANSONE, Livio. Os objetos da identidade negra: consumo, mercantilização, globalização e a criação de culturas negras no Brasil. Mana, Rio de Janeiro, v. 6, n. 1, p. 87-119, 2000.

SIMAS, Luiz Antonio; RUFINO, Luiz. Fogo no mato: a ciência encantada das macumbas. Rio de Janeiro: Mórula, 2018

SPIVAK, Gayatri Chakravorty. Pode o subalterno falar? Belo Horizonte: Ed. UFMG, 2010.

VERGER, Pierre. Fluxo e refluxo do tráfico de escravos entre o Golfo do Benin e a Babia de Todos os Santos dos séculos XVII a XIX. São Paulo: Corrupio, 1987.

YAMAZAKI, Cristina. Editor de texto: quem é e o que faz. São Paulo, 2007. Disponível em http://www.intercom.org.br/papers/nacionais/2007/resumos/R1153-1.pdf. Acesso em 21 jun. 2019.

\section{Informações das autoras}

Vanda Fortuna Serafim

Universidade Estadual de Maringá

E-mail: vfserafim2@uem.br

ORCID: https://orcid.org/0000-0001-7707-7792

Link Lattes: http://lattes.cnpq.br/6264659053959186

Laís Azevedo Fialho Correio

Universidade Estadual de Maringá

E-mail: 1aisfialho2@gmail.com

ORCID: https://orcid.org/0000-0001-6923-5009

Link Lattes: $\underline{\text { http://lattes.cnpq.br/8724898233397030 }}$ 